\title{
RELATIONSHIP BETWEEN AGE AND PARITY WITH INCIDENCES OF ANEMIA IN PREGNANT WOMEN IN MAYANGREJO
}

\author{
Annisa Emma Aznam ${ }^{1}$, Lilik Inayati ${ }^{2}$ \\ ${ }^{1}$ Faculty of Public Health, Universitas Airlangga, 60115 Surabaya, East Java, Indonesia \\ ${ }^{2}$ Mayangrejo Village Midwife, Kalitidu Health Center, Bojonegoro Regency, East Java, Indonesia \\ Corresponding Author: Annisa Emma Aznam \\ Email: annisa.emma.aznam-2016@fkm.unair.ac.id
}

\begin{abstract}
Maternal mortality cases in Indonesia are still high. The Population Survey Census Rates or Survey Penduduk Angka Sensus (SUPAS) data in 2015 found a total of 305 maternal deaths per 100,000 births. Maternal mortality cases can be caused by complications of pregnancy. The age of the pregnant women are linked to their risk for complications during pregnancy. Parity can also affect pregnant women's health conditions. Health problems that can be faced by pregnant women of a risky age and parity are bleeding, which can cause pregnant women to experience anemia. Several studies have found a significant relationship between age and parity with the incidence of anemia in pregnant women. Therefore, it is important to test the relationship between age and parity on the incidence of anemia in pregnant women in Mayangrejo, Bojonegoro. The purpose of this study was to find the relationship between age and parity in the incidences of anemia in pregnant women. The result showed that there is no relationship between age and parity in the incidences of anemia in pregnant women in Mayangrejo, Bojonegoro. This result may be due to the fulfillment of nutritional needs and good knowledge about the risks of pregnancy.
\end{abstract}

Keywords: pregnant women, anemia, age, parity

\begin{abstract}
ABSTRAK
Tingginya angka kasus kematian maternal masih menjadi permasalahan di Indonesia. Data dari Survey Penduduk Angka Sensus (SUPAS) pada tahun 2015, menunjukan bahwa angka total kematian maternal dalam setiap 100.000 kelahiran terdapat 305 kasus. Permasalahan kematian maternal dapat dipengaruhi oleh adanya komplikasi kehamilan. Ibu hamil dengan golongan usia yang terlalu muda ataupun tua berisiko mengalami komplikasi pada masa kehamilan. Begitu juga dengan jumlah paritas ibu hamil yang dapat berpengaruh terhadap kondisi kesehatan ibu hamil. Masalah kesehatan yang dapat dihadapi oleh ibu hamil yang memiliki usia dan paritas yang berisiko yaitu terjadinya pendarahan yang dapat menyebabkan ibu hamil mengalami anemia. Beberapa penelitian menemukan adanya keterkaitan usia dan angka paritas ibu hamil dengan kejadian anemia di masa kehamilan. Oleh sebab itu, penting untuk menguji keberadaan hubungan usia dan jumlah paritas dengan kejadian anemia ibu hamil di Dusun Mayangrejo, Kabupaten Bojonegoro. Penelitian ini bertujuan untuk mengetahui besar hubungan usia dan angka paritas ibu hamil dengan timbulnya anemia pada ibu hamil di Dusun Mayangrejo, Kabupaten Bojonegoro. Hasil penelitian mengemukakan bahwa tidak ada hubungan antara usia dan paritas dengan kejadian anemia ibu hamil di Dusun Mayangrejo. Tidak terdapatnya hubungan antara usia dan jumlah paritas dengan anemia pada ibu hamil di Mayangrejo kemungkinan disebabkan karena kebutuhan gizi yang telah tercukupi dan pengetahuan mengenai risiko kehamilan yang baik.
\end{abstract}

Kata kunci : ibu hamil, anemia, usia, paritas

Accepted: December 08, 2020

\section{INTRODUCTION}

Indonesia has many unresolved health problems. Maternal mortality is one of the health problems in Indonesia that is still unresolved. Data from the 2015 Census Figures Population Survey found a total of 305 maternal deaths per 100,000 births (Indonesian Ministry of Health, 2018). Studies have shown that maternal mortality is influenced by the presence of pregnancy complications.

Pregnant women who are too young or too old have a greater chance of developing complications during pregnancy and are included in the category of high risk pregnancies. Moreover, pregnant women who are in the high-risk age category have a 15 -fold chance of being anemic during pregnancy 
compared to pregnant women who are not in the high-risk age group (Jasmi, 2016).

Pregnant women who are too young are still in their infancy and require a lot of nutritious food intake. Pregnancy requires pregnant women to regulate their diet properly to meet their own nutritional needs and the fetus they are carrying, including the need for iron. Insufficient iron intake in pregnant women can cause anemia (Jasmi, 2016).

On the other hand, a maternal age that is too old is associated with a physiological decline in the body. A pregnancy at an age that is too old can endanger the condition of the mother and contributes to the incidence of anemia. Pregnant women are considered to be too young if they are less than 20 years. While the age of pregnant women who are categorized as too old is more than 35 years (Jasmi, 2016).

The parity rate of pregnant women can also affect the incidence of anemia during pregnancy. The parities of pregnant women who are safe from the onset of anemia are parities 2 and 3. The incidence of anemia is considered to be high for pregnant women with a parity of more than 3 (Amini, Ultimate and Harahap, 2018).

Pregnant women with a parity of 4 or more are at risk for anemia compared to women with 2 and 3 parities. Pregnant women with a parity of 4 or more are at risk for anemia as a high parity number can affect their health condition and unfavorable health conditions can contribute to the onset of anemia in pregnant women (Amini, Ultimate, and Harahap, 2018).

Research conducted by Amanupunnyo, Shaluhiyah, and Margawati (2018) also found a correlation between the parity of pregnant women and the incidence of anemia. Based on their research, the majority of pregnant women with anemia come from the parity category of more than 3. Mothers who have multiple parities are 8-9 times more likely to suffer from anemia compared to pregnant women with 3 parities or more (Amanupunnyo, Shaluhiyah, and Margawati, 2018).

Conversely, women with less than 2 parities can also experience anemia during pregnancy. Pregnant women who do not have previous experience of giving birth often experience difficulties in adapting to their pregnancy. In addition, the lack of experience and knowledge of first-parity pregnant women can also contribute to the incidence of anemia, especially if they do not pay attention to their nutritional needs during pregnancy (Amini, Ultimate and Harahap, 2018).

The problem of anemia during pregnancy is mostly caused by the lack of iron content and the incidence of acute bleeding. Sometimes, the lack of iron content and the occurrence of bleeding interact with each other to cause anemia in pregnant women. Pregnant women are called anemic if the $\mathrm{Hb}$ content in their body is less than $11 \mathrm{~g} \%$ (Amini, Ultimate, and Harahap, 2018).

Anemia in pregnant women is divided into mild and severe anemia. Mild anemia that occurs during pregnancy occurs when the hemoglobin level of the pregnant woman ranges from $8 \mathrm{~g} \%$ - $10.99 \mathrm{~g} \%$. Meanwhile, pregnant women who have hemoglobin levels below $8 \mathrm{~g} \%$ are included in the category of severe anemia (Amini, Ultimate, and Harahap, 2018).

Pregnant women and women who are not pregnant have different normal limits for hemoglobin content, due to differences in the body's physiology during pregnancy. Pregnant women experience a process of hemodilution while pregnant. Hemodilution is the thinning of blood that occurs as a result of an increase in plasma volume (Amini, Ultimate, and Harahap, 2018).

During pregnancy, the increase in plasma volume aims to fulfill of the needs of pregnant women and the fetus in the womb. The increase in plasma volume is of a greater proportion than the increase in the number of red blood cells. Therefore, increasing plasma volume in pregnant women also causes an increase in the need for iron in the body (Wirahartari, Herawati, and Wande, 2019).

Research conducted by Amini, Ultimate, and Harahap (2018) found a strong relationship between age and the incidence of anemia in pregnant women. Anemia was found in pregnant women aged 19 years and under as well as 36 years and over. Meanwhile, pregnant women aged 20 to 35 years are categorized as an age group that is safe from anemia during pregnancy (Amini, Ultimate, and Harahap, 2018). Furthermore, research conducted by Oktaviani, Makalew, and Solang (2016) showed the relationship between the age of pregnant women and $\mathrm{Hb}$ levels. Most pregnant women with low $\mathrm{Hb}$ levels are under 20 years 
of age. Research conducted by Oktaviani, Makalew, and Solang (2016) also found a link between the number of parity and anemia that occur in pregnant women (Oktaviani, Makalew, and Solang, 2016).

Several studies have found a relationship between the age of pregnant women and parity with the incidence of anemia during pregnancy. Therefore, it is important to examine this relationship for pregnant women in Mayangrejo village, Bojonegoro Regency. The purpose of this study was to determine the relationship between the age of pregnant women and the parity rate with the incidence of anemia in pregnant women in Mayangrejo village, Bojonegoro Regency.

\section{METHODS}

This research belongs to the category of associative research which aims to analyze the relationship between two or more research variables (Timothy, 2017). The research data obtained are secondary data from the recording of the midwife of the Mayangrejo village, Kalitidu Health Center, Bojonegoro Regency. The data used includes data on age and parity with the anemia status of pregnant women that have been recorded by the Mayangrejo village health post or Pondok Kesehatan Desa (Ponkesdes). A sample of 45 pregnant women were randomly selected in Mayangrejo village, Kalitidu District, Bojonegoro Regency were the subjects of this study. Data on age and parity with the anemia status of pregnant women in Mayangrejo village was analyzed using the chi-square Fisher exact test.

The Chi-square fisher exact test is a statistical test method used to analyze the relationship between 2 variables that have a small sample size. The Chi-square Fisher exact test can produce values that indicate the relationship between age and parity with the presence of anemia in pregnant women. The Chi-square Fisher exact test method is also an alternative method that was used if the expected value or expected value obtained from the $2 \times 2$ Chi-square test is more than $20 \%$ or less than 5 (Sani, 2016).

The test regarding the relationship between variables refers to the $p$-value obtained. If the p-value is less than the value of 0.05 , it is concluded that there is a relationship between the variables studied. The p-value can also be written mathematically as follows:

$$
\begin{aligned}
\text { p-value } & =\frac{\left(\begin{array}{c}
n_{1} \\
n_{11}
\end{array}\right)\left(\begin{array}{c}
n_{2} \\
n_{12}
\end{array}\right)}{\left(\begin{array}{c}
n \\
n_{1}
\end{array}\right)} \\
& =\frac{\left(\frac{\left(n_{1}\right) !}{\left(n_{11}\right) !\left(n_{21}\right) !}\right)\left(\frac{\left(n_{2}\right) !}{\left(n_{12}\right) !\left(n_{22}\right) !}\right)}{\left(\frac{(n) !}{\left(n_{11}\right) !\left(n_{12}\right) !}\right) !} \\
& =\frac{\left(n_{1}\right) !\left(n_{2}\right) !\left(n_{1}\right) !\left(n_{2}\right) !}{(n) !\left(n_{11}\right) !\left(n_{12}\right) !\left(n_{21}\right) !\left(n_{22}\right) !}
\end{aligned}
$$

The value of $\mathrm{n}$ is the total sample obtained from $n 11+n 12+n 21+n 22$. The value of $n .1$ represents the total sample with category 1 on variable $B$ resulting from $\mathrm{n} 11+\mathrm{n} 21$ and n. 2 is obtained from $n 12+n 22$ which states the total sample category 2 on variable $B$. While the value of $\mathrm{n} 1$. states the total sample with category 1 on variable A, resulting from $\mathrm{n} 11+$ $\mathrm{n} 12$ and $\mathrm{n} 2$. Obtained from $\mathrm{n} 21+\mathrm{n} 22$ which states the total sample category 2 on variable A (Mufarrikoh, 2019).

\section{RESULTS}

Based on data from the Mayangrejo village health post records in March 2018 to April 2019, there were 45 pregnant women in Mayangrejo, Kalitidu District, Bojonegoro Regency. The age of pregnant women in the aforementioned records are categorized into high-risk and not high-risk categories and is presented in table 1 . The high-risk age category is for pregnant women aged 19 years or under and pregnant women aged 36 years or more. Meanwhile, pregnant women who are not classified in the high-risk age group are within the age group of 20 to 35 years.

The frequency distribution, which is presented in table 1, finds that the majority of the age of pregnant women are not included in the age group of high-risk pregnant women. As many as $84 \%$ or the equivalent of 38 pregnant women are not high-risk pregnant women. On the other hand, a small proportion of them are pregnant women who fall into the high-risk age category. A total of 7 pregnant women or $16 \%$ of the pregnant women in the Mayangrejo village data are classified within the high-risk age.

Table. 2 presents the parity categories of pregnant women in Mayangrejo village. Pregnant women in the high-risk parity category are pregnant women with parity rates of less than 2 or more than 3. Meanwhile, 
pregnant women who are not included in the high-risk parity category are pregnant women with parity rates of 2 and 3 .

The frequency distribution presented in Table 2 shows that the majority of parity rates of pregnant women in Mayangrejo village are in the high-risk category. As many as $87 \%$ or equivalent to 39 pregnant women are pregnant women with a high-risk parity. Only a small proportion of the sample are pregnant women who fall into the low-risk parity category. A total of 6 pregnant women or $13 \%$ of pregnant women in Mayangrejo village are not included in the high-risk parity group.

The data on hemoglobin $(\mathrm{Hb})$ levels of pregnant women in Mayangrejo village was used as a reference to determine the presence of anemia in pregnant women. The category of anemia is given to subjects with $\mathrm{Hb}$ levels below $11 \mathrm{~g} \%$. Meanwhile, if the subject's $\mathrm{Hb}$ level reaches $11 \mathrm{~g} \%$ or more, it is categorized as not anemic. Secondary data of $\mathrm{Hb}$ levels were divided into 2, $\mathrm{Hb}$ levels that are categorized as anemic are presented in table 3 . In the frequency distribution shown in table 3 , it was found that only a small number of subjects were anemic. Only 2 subjects or $4 \%$ of the subjects had anemia. The absence of anemia was found in the majority of research subjects. $96 \%$ of the subjects or the equivalent of 43 research subjects did not experience anemia.
Table 1. Age Category Distribution of Pregnant Women in Mayangrejo village, Bojonegoro Regency

\begin{tabular}{lcc}
\hline $\begin{array}{c}\text { Age Category } \\
\text { (High Risk) }\end{array}$ & Amount & $\begin{array}{c}\text { Percentage } \\
(\boldsymbol{\%})\end{array}$ \\
\hline Yes & 7 & 16 \\
No & 38 & 84 \\
Total & 45 & 100 \\
\hline
\end{tabular}

Table 2. Maternal Parity Category Distribution of Pregnant Women in Mayangrejo village, Bojonegoro Regency

\begin{tabular}{lcc}
\hline $\begin{array}{c}\text { Parity Category } \\
\text { (High Risk) }\end{array}$ & Amount & $\begin{array}{c}\text { Percentage } \\
(\boldsymbol{\%})\end{array}$ \\
\hline Yes & 39 & 87 \\
No & 6 & 13 \\
Total & 45 & 100 \\
\hline
\end{tabular}

Table 3. Distribution of the Frequency of Anemia in Pregnant Women in Mayangrejo village, Bojonegoro Regency

\begin{tabular}{lcc}
\hline $\begin{array}{c}\text { Incidence of } \\
\text { Anemia }\end{array}$ & Amount & $\begin{array}{c}\text { Percentage } \\
(\boldsymbol{\%})\end{array}$ \\
\hline Yes & 2 & 4 \\
No & 43 & 96 \\
Total & 45 & 100 \\
\hline
\end{tabular}

Table 4. Results of Testing the Relationship of Age and Parity with the Incidence of Anemia in Pregnant Women in Mayangrejo village, Bojonegoro Regency

\begin{tabular}{|c|c|c|c|c|}
\hline \multirow{2}{*}{ Variable } & \multirow{2}{*}{ Category } & \multicolumn{2}{|c|}{ Incidence of Anemia } & \multirow[b]{2}{*}{$\mathbf{p}$} \\
\hline & & Yes & No & \\
\hline \multirow{2}{*}{ Mother's Age } & High Risk & $1(14 \%)$ & $6(86 \%)$ & \multirow{2}{*}{0.290} \\
\hline & Not High Risk & $1(3 \%)$ & $37(97 \%)$ & \\
\hline Mother's Parity & $\begin{array}{l}\text { High Risk } \\
\text { Not High Risk }\end{array}$ & $\begin{array}{c}1(3 \%) \\
1(17 \%)\end{array}$ & $\begin{array}{c}38(97 \%) \\
5(83 \%)\end{array}$ & 0.252 \\
\hline
\end{tabular}

The data on hemoglobin $(\mathrm{Hb})$ levels of pregnant women in Mayangrejo village was used as a reference to determine the presence of anemia in pregnant women. The category of anemia is given to subjects with $\mathrm{Hb}$ levels below $11 \mathrm{~g} \%$. Meanwhile, if the subject's $\mathrm{Hb}$ level reaches $11 \mathrm{~g} \%$ or more, it is categorized as not anemic. Secondary data of $\mathrm{Hb}$ levels were divided into 2, $\mathrm{Hb}$ levels that are categorized as anemic are presented in table 3 . In the frequency distribution shown in table 3, it was found that only a small number of subjects were anemic.
Only 2 subjects or $4 \%$ of the subjects had anemia. The absence of anemia was found in the majority of research subjects. $96 \%$ of the subjects or the equivalent of 43 research subjects did not experience anemia.

The testing results of the relationship between maternal age and parity with the incidence of anemia in pregnant women in Mayangrejo village are presented in table 4 . The p-value obtained from the testing is 0.219 . Likewise, when testing the relationship between parity and the incidence of anemia in pregnant 
women in Mayangrejo village the p-value obtained is 0.252 . Both p-values are greater than 0.05 , therefore it can be concluded that maternal age and parity are not related to the incidence of anemia in pregnant women in Mayangrejo village.

\section{DISCUSSION}

\section{The Effect of Age on the Presence of Anemia in Pregnant Women}

Research conducted on pregnant women in Mayangrejo village showed that age does not influence the incidence of anemia in pregnancy. Most of the pregnant women in Mayangrejo village within the at-risk age category did not experience anemia during pregnancy. However, Oktaviani, Makalew, and Solang (2016) stated that there is a strong relationship between age and hemoglobin $(\mathrm{Hb})$ levels. Research conducted at the Ranomuut Health Center also revealed that low Hb levels are dominantly found in pregnant women within the high-risk age category, namely the age group of fewer than 20 years.

Moreover, according to Amini, Pamungkas, and Harahap (2018), there is a strong relationship between age and the incidence of anemia in pregnancy. Anemia was found in the age category of under 20 years and over 35 years. While the age group of 20 to 35 years is an age category that is at low risk of experiencing anemic conditions (Amini, Pamungkas, and Harahap, 2018).

This research is in line with research at the Pantai Cermin Health Center. Research conducted by Maulidanita and Raja (2018) found a weak relationship between the age of pregnant women and the incidence of anemia, or it could be said that there was no relationship between the two. This study also found that the incidence of anemia was dominated by the age group of 20 to 30 years.

Similar results were also found in the study of Tanziha, Utama, and Rosmiati (2016). The study used Basic Health Research or Riset Kesehatan Dasar data in 2013 which explained that in Indonesia, pregnant women aged 20 years and under and 35 years old and above have a higher risk for anemia compared to the age group 20 to 35 years. However, after testing the relationship between the two, the test results showed a weak relationship. Therefore, it can be said that the age of pregnant women is very unlikely to affect the incidence of anemia, because of the weak relationship between the two.

This study found that there is no relationship between the high-risk age category and the incidence of anemia in pregnant women in Mayangrejo village. This is most lilkely because the nutrition of pregnant women in Mayangrejo village who are less than 20 years old has been fulfilled. According to research conducted by Aisyah and Fitriayani (2016), pregnant women who are young or under 20 years old require a lot of nutritious food intake because they are still classified as teenagers. Adolescence is a phase where the body is still experiencing the growth and development needed to achieve optimal function. Therefore, pregnant women in their teens need a lot of nutritious food intake to meet the needs of the fetus in the womb, as well as to meet their growth and development. However, pregnancy for women under the age of 20 years may cause risks to the pregnant women and the fetus they are carrying because their reproductive system is still not ready for pregnancy (Jasmi, 2016).

According to the results of this study, there is no tendency for anemia in pregnant women in Mayangrejo village who are over 35 years old, this may be because pregnant women in the village consume iron tablets regularly. Regular consumption of iron tablets can help pregnant women's $\mathrm{Hb}$ levels to remain in normal conditions, especially pregnant women aged 35 years and over who are prone to anemia due to a decrease in body physiology (Anfiksyar et al., 2019). Pregnant women entering the age of 36 years and over begin to regenerate body cells, and this includes the reproductive system. Therefore, pregnancy becomes riskier for pregnant women who are more than 35 years old.

A similar opinion was also expressed by Astriana (2017), she stated that anemia in pregnant women who are above 35 years of age occurs due to a decrease and decline in the body's defense system, as well as the risk of the emergence of several diseases that often afflict individuals who are more than 35 years old. In addition, according to Khasanah and Sudilah (2016), pregnant women aged over 35 years who suffer from anemia are caused by a decrease in iron reserves as a cause of fertilization. 
Anemia can also be affected by the lack of consumption of nutritious foods during the pregnancy phase, especially foods rich in iron content. In addition, anemia can also be caused by mistakes in choosing foods that can inhibit the body from absorbing iron from food (Paendong, Suparman and Tendean, 2016). During pregnancy, pregnant women need 1000 $\mathrm{mg}$ of iron. The need for iron during pregnancy is not sufficient if it is obtained only from food (Wirahartari, Herawati, and Wande, 2019). Thus, pregnant women also require additional consumption of iron tablets.

Additional intake of iron tablets that are given to pregnant women is often in the form of ferrous fumarate salt, ferrous gluconate, and ferrous sulfate. The ferrous sulfate, gluconate, and fumarate salts generally work effectively to increase the $\mathrm{Hb}$ levels of pregnant women. Iron tablets in the form of ferrous sulfate with a dose of $60 \mathrm{mg}$ per day, can increase the $\mathrm{Hb}$ of pregnant women up to $1 \mathrm{~g} \%$ per month. In addition to being effective in increasing the $\mathrm{Hb}$ level of pregnant women, iron tablets in the form of ferrous sulfate, gluconate, and fumarate salts also have a fairly affordable price (Deswati, Suliska and Maryam, 2019).

Not only pregnant women in the atrisk age group, pregnant women in the lowrisk age group who have an age range of 20 to 35 years also do not rule out anemia, even though it is considered a safe age for pregnancy. Anfiksyar et al. (2019) found that the majority of pregnant women with anemia were in the age range of 20 to 35 years. The incidence of anemia in pregnant women aged 20 to 35 years is due to the short distance between pregnancies. Likewise, Khasanah and Sudilah (2016) found that at the Sanden Health Center, Bantul, Yogyakarta, anemia is dominated by pregnant women aged 20 to 35 years. They stated that the possibility of anemia in the age range of 20 to 35 years was because the pregnant women were still actively working.

\section{The Effect of Parity on the Presence of Anemia in Pregnant Women}

The results of the study on pregnant women in Mayangrejo village showed that parity has no relationship with the incidence of anemia in pregnant women. The results of this study contradict the research of Amanupunnyo, Shaluhiyah, and Margawati (2018), which found that parity affects the incidence of anemia in pregnant women. Moreover, Oktaviani, Makalew, and Solang (2016), explained that parity can influence the $\mathrm{Hb}$ levels of pregnant women so parity is also referred to as one of the determinants that affect the occurrence of anemia in pregnant women.

However, several other studies have presented results that are in line with this study. Abidah (2019), found no correlation between parity and anemia in pregnant women. Similar to the findings of Abidah (2019), the research of Sjahriani and Faridah (2019) also found that parity rate is not related to the incidence of anemia in pregnant women.

Based on the results of this study, there is no correlation between parity and anemia in pregnant women in Mayangrejo village. This may possibly be because they already have sufficient knowledge about the risks of pregnancy, including anemia. Pregnant women who are in the high-risk parity category come from a parity of less than 2. Pregnant women with a parity of less than 2 are at risk of anemia due to the lack of experience and knowledge about pregnancy. The experience and knowledge of pregnant women with low first parity can have an impact on the lack of fulfillment of the nutritional needs needed during pregnancy, thus there is a risk for anemia for this category of pregnant women (Amini, Ultimate and Harahap, 2018). On the other hand, this condition was not found in this study. Therefore, there may be no relationship between parity and anemia in pregnant women because pregnant women already know and are aware of the nutritional needs that must be met during pregnancy.

\section{CONCLUSIONS AND SUGGESTIONS}

\section{Conclusion}

The majority of pregnant women in Mayangrejo village, Bojonegoro Regency are not anemic. Most of the pregnant women who are not anemic come from the non-high-risk age category. The results of statistical tests showed that there was no relationship between age and parity with the incidence of anemia in pregnant women in Mayangrejo village. The absence of a relationship between the age and parity of pregnant women with the incidence of anemia may be due to adequate nutritional needs and good knowledge about the risks of pregnancy. 


\section{Suggestions}

There are 2 research subjects or $4 \%$ of pregnant women who are anemic. Although the percentage of anemia in pregnant women in Mayangrejo village is relatively low, it is still necessary to be aware of the possibility of conditions that can endanger the health of pregnant women or the babies they are carrying. It is necessary to further explore the possible factors that cause pregnant women in Mayangrejo village to experience anemia. Through tracing the causes of anemia in subjects, it is hoped that efforts to prevent complications in pregnant women can be more effective and efficient.

\section{REFERENCES}

Aisyah, R. D. dan Fitriayani, 2016. FaktorFaktor Internal dan Eksternal yang Berhubungan dengan Kejadian Anemia di Wilayah Kabupaten Pekalongan. Jurnal Motorik, 11, pp. 41-49.

Abidah, S.N., 2019. Analisis Faktor-faktor yang Berhubungan dengan Kejadian Anemia pada Ibu Hamil Trisemester III di BPM Kusmawati Surabaya. Jurnal Ilmiah Kesehatan (Journal of Health Science), 12 (2), pp. 99-108.

Amanupunnyo, N. A., Shaluhiyah, Z. dan Margawati, A., 2018. Analisis Faktor Penyebab Anemia pada Ibu Hamil di Puskesmas Kairatu Seram Barat. Jurnal Aisyah: Jurnal Ilmu Kesehatan, 3(2), pp. 173-181.

Amini, A., Pamungkas, C.E. dan Harahap, A.P.H.P., 2018. Usia Ibu dan Paritas Sebagai Faktor Risiko yang Mempengaruhi Kejadian Anemia pada Ibu Hamil di Wilayah Kerja Puskesmas Ampenan. Midwifery Journal: Jurnal Kebidanan UM. Mataram, 3(2), p.108.

Anfiksyar, K.S.S., Aryana, M.B.D., Surya, I.G.N.H.W. dan Manuaba, I.B.G.F., 2019. Karakteristik Anemia pada Kehamilan di Poliklinik Kebidanan PSUP Sanglah Tahun 2016-2017. Jurnal Medika Udayana, 8(7), pp. $1-7$.

Astriana, W., 2017. Kejadian Anemia pada Ibu Hamil Ditinjau dari Paritas dan Usia. Jurnal Aisyah: Jurnal Ilmu Kesehatan, 2(2), pp. 123-130.
Deswati, D.A., Suliska, N. dan Maryam, S., 2019. Pola Pengobatan Anemia Pada Ibu Hamil di Salah Satu Rumah Sakit Ibu dan Anak. Pola Pengobatan Anemia Pada Ibu Hamil di Salah Satu Rumah Sakit Ibu dan Anak, 5(1), pp. 13-21.

Indonesian Ministry of Health, 2018. Profil Kesehatan Indonesia 2018. [online] Available at: <website:http://www.kemkes.go>.

Jasmi, 2016. Hubungan antara Paritas dan Umur dengan Kejadian Anemia pada Ibu Hamil di Puskesmas Melur Kecamatan Sukajadi Kota Pekanbaru. Jurnal Ibu dan Anak, 1(2), pp. 43-50.

Khasanah, Y.U. dan Sudilah, 2016. Gambaran Karakteristik Anemia pada Ibu Hamil di Puskesmas Sanden Bantul Yogyakarta. Jurnal Ilmu Kebidanan, 4(2), pp.110-117.

Maulidanita, R. dan Raja, S.L., 2018. Hubungan Karakteristik Ibu Hamil dengan Status Anemia pada Trimester II dan III di Puskesmas Pantai Cermin Kabupaten Serdang Bedagai. Jurnal Bidan Komunitas, 1(2), p.86.

Mufarrikoh, Z., 2019. Statistika Pendidikan (Konsep Sampling dan Uji Hipotesis). [online] Surabaya: Jakad Media Publishing. Available at: <https://books.google.co.id/>

Oktaviani, I., Makalew, L. dan Solang, S., 2016. Profil Haemoglobin Pada Ibu Hamil Dilihat dari Beberapa Faktor Pendukung. Jurnal Ilmiah Bidan, 4(1), p.90985.

Paendong, F.T., Suparman, E. dan Tendean, H.M.M., 2016. Profil Zat Besi (Fe) pada Ibu Hamil dengan Anemia di Puskesmas Bahu Manado. e-CliniC, 4(1), pp. 369-374.

Sani, F.K., 2016. Metodologi Penelitian: Farmasi Komunitas dan Eksperimental. [online] Yogyakarta: Deepublish. Available at: <https://books.google.co.id/>

Sjahriani, T. dan Faridah, V., 2019. Faktorfaktor yang Berhubungan dengan Kejadian Anemia pada Ibu Hamil. Jurnal Kebidanan, 5(2), pp. 106-155.

Tanziha, I., Utama, L.J. dan Rosmiati, R., 2016. Faktor Risiko Anemia Ibu Hamil Di Indonesia. 11(2), pp.143-152. 
137 Jurnal Biometrika dan Kependudukan, Volume 10, Issue 2 December 2021: 130-137

Timotius, K.H., 2017. Pengantar Metodologi Penelitian: Pendekatan Manajemen Pengetahuan untuk Perkembangan Pengetahuan. [online] Yogyakarta: Penerbit Andi. Available at: <https://books.google.co.id/>
Wirahartari, L.M., Herawati, S. dan Wande, N., 2019. Gambaran Indeks Eritrosit Anemia Pada Ibu Hamil Di RSUP Sanglah Denpasar Tahun 2016. Jurnal Medika, 8(5), pp.2597-8012. 